\title{
Determinants of Using Gadget to Concentration, Complaints of Eye Fatigue and Student Learning Motivation at SMKN 7 Malang
}

\author{
Rohmahtun Naryaning, \\ Katmini \\ Health Promotion, Public \\ Health, Institute of Health \\ Sciences Strada Indonesia \\ Email: \\ dmasa2196@gmail.com
}

Received : October $4^{\text {nd }} 2021$

Accepted : October $15^{\text {rd }} 2021$

Published : November $27^{\text {th }} 2021$

\begin{abstract}
The development of information and communication technology brings an influence on many fronts, is no exception in the world of education. Including the use of gadgets that increasingly exist in the world of education. But the use of gadgets must also be monitored by the duration, frequency and intensity that support concentration, reduce eye fatigue complaints and motivation to learn for the better. The purposes of this study are to explain the influence of duration, frequency and intensity of gadget use on student concentration, eye fatigue complaints, students learning motivation at SMKN 7 Malang. This research design uses a correlative study with a quantitative approach. The research subjects were 195 students. Data collection techniques using a questionnaire. The data analysis technique used multiple linear regression analysis. The results of this research indicate that: there was a negative influence of duration, frequency, and intensity of using gadget on student concentration at SMKN 7 Malang. There was a positive influence of duration, frequency, and intensity of using gadget on student eye fatigue complaints at SMKN 7 Malang. There is a negative influence of duration, frequency, and intensity of using gadget on students learning motivation at SMKN 7 Malang. This study shows that there is a need for health promotion so that students reduce the duration, frequency of using gadgets as an effort to increase concentration, prevent eye fatigue and increase learning motivation.
\end{abstract}

Keywords: Complaints, eye fatigue, concentration, duration, frequency, intensity, learning motivation

Copyright @ 2021 IIK STRADA Indonesia All right reserved.

This is an open-acces article distributed under the terms of the Creative Commons Attribution-ShareAlike 4.0 International License.

\section{INTRODUCTION}

The development of technology and information is progressing very rapidly, marked by advances in the field of information and technology. The Indonesian nation is one of the nations that is involved in the advancement of information media and technology (Ameliola \& Nugraha, 2013). The increasing use of gadgets or tools that can be easily connected to the internet has increased from time to time. Gadgets are sophisticated goods created with various applications that can present various news media, social networks, hobbies, and even entertainment. This sophisticated item, which is seen from a price that cannot be considered cheap, is not only used as a medium of entertainment, but with applications that are continuously updated, the gadget must be used by people who have business interests, or work on college and office assignments (Widiawati \& Sugiman, 2015 ). 
Indonesia ranks fifth after visitors from America, England, France and Italy with 50,489,360 users. Based on the results of research in Indonesia, the use of the internet is currently growing rapidly. The number of additional Internet users in Indonesia in the last 1 year has reached $1000 \%$ or means a 10-fold growth. As many as 53\% of the youth access via cell phones. The Association of Indonesian Internet Service Providers in 2014 stated that internet users in Indonesia were estimated to reach 25 million. Annual growth is an average of 25\%. Most users are 15-39 years old. From the results of a preliminary study conducted at SMKN 7 Malang, it was found that in the 2018-2019 school year, class XI had 370 students. There are four majors, namely Analytical Chemistry, Catering, Boutique Clothing and Multimedia. From the results of a preliminary study conducted on 8 students in each department, it was found that out of 32 students, all have gadgets and active users. They usually use gadgets between 4-6 hours per day. Several students commented on the complaints of eye fatigue that they suffered from using gadgets. Due to the distance that is too close and the duration of use is too long.

The US Department of Health and Human Services (2011) released a report on the minimum time limit for viewing computer monitors or gadget screens and televisions in a day, which is a maximum of 2 hours a day. According to the National Institute of Occupational Safety and Health, eye fatigue affects about $90 \%$ of people who spend 3 hours or more per day in front of a computer or screen (Pheasant, 2013). Eye fatigue has symptoms or complaints such as a feeling of tension or pain in the eyes, red eyes, a burning feeling in the eyes accompanied by a heavy feeling in the forehead (Ilyas, 2012). Such conditions tend to reduce accuracy and can further cause errors, extend working time, reduce production, besides that it can also reduce alertness and tend to work accidents or increase accident rates, and affect work morale (Soeripto, 2013).

Sardiman (2012) The concentration will be optimal if there is the right motivation. So that learning motivation is something that cannot be separated from the teaching and learning process carried out by a teacher to his students, especially on student learning outcomes to be achieved. Learning motivation is the overall motivation of students which is the cause of learning activities that can ensure the continuity of learning activities and provide direction for these learning activities, in order to achieve the expected goals (Kartini, 2014). In learning activities, motivation is a very important factor. Motivation provides encouragement and encourages people to engage in activities. The level of student learning motivation can show the success of learning. Motivation is not only important to make students do learning activities, but also determines how much students can learn from the activities they do or the information they encounter. Motivated students show high cognitive processes in learning, absorbing, and remembering what they have learned (Rifa'i, 2012). Students or students who are highly motivated in learning will likely obtain high learning outcomes as well. This means that the higher the motivation, the higher the intensity of the effort, and the efforts made, the higher the learning outcomes obtained. The use of gadgets on students will greatly affect concentration and learning motivation, because basically with this gadget, students are expected to be able to overcome the limitations of knowledge and information that the teacher cannot explain. But on the other hand, the use of this gadget can also reduce concentration causing eye fatigue complaints which have an impact on students' learning motivation.

Based on the problems above, researchers are interested in conducting research on "Determinants of Gadget Use on Concentration, Complaints of Eye Fatigue and Student Learning Motivation at SMKN Malang".

\section{MATERIALS AND METHODS}

The research design uses a correlative study with a quantitative approach. The dependent variable is duration (X1), frequency (X2), intensity of gadget use (X3) while the independent variables are concentration (Y1), eye fatigue complaints (Y2) and learning motivation (Y3). The population is 390 students. In this study, the sample was taken using a stratified random sampling technique with a sample of 195 students. How to collect data using a questionnaire. The data analysis technique used multiple linear regression analysis. This research has gone ethical approval with Etic Code: 431/KEPK/V/2021 issued by IIK Strada Indonesia. 


\section{RESULTS}

Table 1. T-Test $\mathrm{X} 1$ to $\mathrm{Y} 1$

\begin{tabular}{|l|l|l|l|}
\hline T-Test & $\mathrm{T}_{\text {count }}$ & Significance & $\mathrm{T}_{\text {table }}$ \\
\hline $\mathrm{X}_{1}$ & -2.305 & .015 & $-1,972$ \\
\hline
\end{tabular}

Based on the results of the regression analysis table above, the following results were obtained:

The variable duration of gadget use has a tcount of $-2,305$ with a significance of 0.015 . Because tcount $>$ ttable $(-2,305>-1,972)$ or sig. $\mathrm{T}<5 \%(0.015<0.05)$ it can be concluded that $\mathrm{H} 0$ is rejected and $\mathrm{H} 1$ is accepted so that the variable duration of gadget use has a significant effect on the concentration of class X students at SMKN 7 Malang.

Table 2. T-Test $\mathrm{X} 2$ to $\mathrm{Y} 1$

\begin{tabular}{|l|l|l|l|}
\hline T-Test & $\mathrm{T}_{\text {count }}$ & Significance & $\mathrm{T}_{\text {table }}$ \\
\hline $\mathrm{X}_{2}$ & -2.218 & .028 & $-1,972$ \\
\hline
\end{tabular}

Based on the results of the regression analysis table above, the following results were obtained:

The variable frequency of gadget use has a tcount of -2.218 with a significance of 0.028 . Because tcount $>$ ttable $(-2.218>-1.972)$ or sig. $\mathrm{T}<5 \%(0.028<0.05)$ it can be concluded that $\mathrm{H} 0$ is rejected and $\mathrm{H} 1$ is accepted so that the variable frequency of gadget use has a significant effect on the concentration of class X students at SMKN 7 Malang.

Table 3. T-Test $\mathrm{X} 3$ to $\mathrm{Y} 1$

\begin{tabular}{|l|l|l|l|}
\hline T-Test & $\mathrm{T}_{\text {count }}$ & Significance & $\mathrm{T}_{\text {table }}$ \\
\hline $\mathrm{X}_{3}$ & -2.710 & .007 & $-1,972$ \\
\hline
\end{tabular}

Based on the results of the regression analysis table above, the following results were obtained:

The variable intensity of gadget use has a tcount of $-2,710$ with a significance of 0.007 . Because tcount $>$ ttable $(-2.710>-1.972)$ or sig. $\mathrm{T}<5 \%(0.007<0.05)$ it can be concluded that $\mathrm{H} 0$ is rejected and $\mathrm{H} 1$ is accepted so that the variables of duration, frequency, intensity of gadget use have a significant negative effect on the concentration of class X students at SMKN 7 Malang.

Table 4. T-test $\mathrm{X} 1$ to $\mathrm{Y} 2$

\begin{tabular}{|l|l|l|l|}
\hline T-Test & $\mathrm{T}_{\text {count }}$ & Significance & $\mathrm{T}_{\text {table }}$ \\
\hline $\mathrm{X}_{1}$ & 2.936 & .014 & 1,972 \\
\hline
\end{tabular}

Based on the results of the regression analysis table above, the following results were obtained:

The variable duration of gadget use has a tcount of 2,936 with a significance of 0.014 . Because tcount $>$ ttable $(2,936>1,972)$ or sig. $\mathrm{T}<5 \%(0.014<0.05)$ it can be concluded that $\mathrm{H} 0$ is rejected and $\mathrm{H} 1$ is accepted so that the variable duration of gadget use has a significant positive effect on eye fatigue complaints of class X students at SMKN 7 Malang.

Table 5. T-test X2 to Y2

\begin{tabular}{|l|l|l|l|}
\hline $\mathrm{T}$-Test & $\mathrm{T}_{\text {count }}$ & Significance & $\mathrm{T}_{\text {table }}$ \\
\hline $\mathrm{X}_{2}$ & 2.080 & .008 & 1,972 \\
\hline
\end{tabular}

Based on the results of the regression analysis table above, the following results were obtained:

The variable frequency of gadget use has a tcount of 2,080 with a significance of 0.008 . Because tcount > ttable $(2.080>1.972)$ or sig. $\mathrm{T}<5 \%(0.008<0.05)$ it can be concluded that $\mathrm{H} 0$ is rejected and $\mathrm{H} 1$ is accepted so that the variable frequency of gadget use has a significant positive effect on eye fatigue complaints of class $\mathrm{X}$ students at SMKN 7 Malang.

Table 6. T-test X3 to Y2

\begin{tabular}{|l|l|l|l|}
\hline $\mathrm{T}$-Test & $\mathrm{T}_{\text {count }}$ & Significance & $\mathrm{T}_{\text {table }}$ \\
\hline $\mathrm{X}_{3}$ & 2.580 & .011 & 1,972 \\
\hline
\end{tabular}

Based on the results of the regression analysis table above, the following results were obtained:

The variable intensity of gadget use has a tcount of 2,580 with a significance of 0.011 . Because tcount $>$ ttable $(2,580>1,972)$ or sig. $\mathrm{T}<5 \%(0.011<0.05)$ it can be concluded that $\mathrm{H} 0$ is rejected and $\mathrm{H} 1$ is accepted so that the variable intensity of gadget use has a significant positive effect on eye fatigue complaints of class X students at SMKN 7 Malang.

Table 7. T-test X1 to $\mathrm{Y} 3$

\begin{tabular}{|l|l|l|l|}
\hline T-Test & $\mathrm{T}_{\text {count }}$ & Significance & $\mathrm{T}_{\text {table }}$ \\
\hline $\mathrm{X}_{1}$ & -2.265 & .017 & $-1,972$ \\
\hline
\end{tabular}

Based on the results of the regression analysis table above, the following results were obtained:

The variable duration of gadget use has a tcount of -2.265 with a significance of 0.017 . Because tcount $>$ ttable $(-2.265>-1.972)$ or sig. $\mathrm{T}<5 \%(0.017<0.05)$ it can be concluded that $\mathrm{H} 0$ is rejected and $\mathrm{H} 1$ is accepted so that the variable duration of gadget use has a significant effect on the learning motivation of class X students at SMKN 7 Malang. 
Determinants of Using Gadget to Concentration, Complaints of Eye Fatigue.....

Table 8. T-test $\mathrm{X} 2$ to $\mathrm{Y} 3$

\begin{tabular}{|l|l|l|l|}
\hline T-Test & $\mathrm{T}_{\text {count }}$ & Significance & $\mathrm{T}_{\text {table }}$ \\
\hline $\mathrm{X}_{2}$ & -2.083 & .011 & $-1,972$ \\
\hline
\end{tabular}

Based on the results of the regression analysis table above, the following results were obtained:

The variable frequency of gadget use has a tcount of $-2,083$ with a significance of 0.011 . Because tcount > ttable $(-2.083>-1.972)$ or sig. $\mathrm{T}<5 \%(0.006<0.05)$ it can be concluded that $\mathrm{H} 0$ is rejected and $\mathrm{H} 1$ is accepted so that the variable frequency of gadget use has a significant effect on the learning motivation of class X students at SMKN 7 Malang.

Table 9. T-test $\mathrm{X} 3$ to $\mathrm{Y} 3$

\begin{tabular}{|l|l|l|l|}
\hline T-Test & $\mathrm{T}_{\text {count }}$ & Significance & $\mathrm{T}_{\text {table }}$ \\
\hline $\mathrm{X}_{3}$ & -2.793 & .006 & $-1,972$ \\
\hline
\end{tabular}

Based on the results of the regression analysis table above, the following results were obtained:

The variable intensity of gadget use has a tcount of -2.793 with a significance of 0.006 . Because tcount > ttable $(-2.793>-1.972)$ or sig. $\mathrm{T}<5 \%(0.006<0.05)$ it can be concluded that $\mathrm{H} 0$ is rejected and $\mathrm{H} 1$ is accepted so that the variable intensity of gadget use has a significant effect on the learning motivation of class X students at SMKN 7 Malang.

Table 10. F-Test X1, X2, X3 to Y1

\begin{tabular}{|c|c|c|}
\hline$F_{\text {count }}$ & Significance & $F_{\text {table }}$ \\
\hline 90.985 & .000 & 2,65 \\
\hline
\end{tabular}

Analysis in this study. declared eligible to be used if the significance value $<0.05$. The results of this calculation are $0.000<0.05$, it can be concluded that: 1 . The variable duration of gadget use (X1), frequency of gadget use (X2) and intensity of gadget use (X3) have a significant effect on the concentration variable (Y1).

Table 11. F-test $X_{1}, X_{2}, X_{3}$ to $Y_{2}$

\begin{tabular}{|c|c|c|}
\hline $\mathrm{F}_{\text {count }}$ & Signifikansi & $\mathrm{F}_{\text {table }}$ \\
\hline 84.363 & $.000^{\mathrm{b}}$ & 2,65 \\
\hline
\end{tabular}

Analysis in this study. declared eligible to be used if the significance value $<0.05$. The results of this calculation are $0.000<0.05$, the variable duration of gadget use (X1), frequency of gadget use (X2) and intensity of gadget use (X3) have a significant effect on eye fatigue complaints variable (Y2).

Table 12. F-test $X_{1}, X_{2}, X_{3}$ terhadap $Y_{3}$

\begin{tabular}{|c|c|c|}
\hline $\mathrm{F}_{\text {count }}$ & Significance & $\mathrm{F}_{\text {table }}$ \\
\hline 86.675 & $.000^{\mathrm{b}}$ & 2,65 \\
\hline
\end{tabular}

Analysis in this study. declared eligible to be used if the significance value $<0.05$. The results of this calculation are $0.000<0.05$, the variable duration of gadget use (X1), frequency of gadget use (X2) and intensity of gadget use (X3) have a significant influence on learning motivation variable (Y3).

Table 13. Coefficient of Determination $X_{1}, X_{2}, X_{3}$ to $Y_{1}$

Model Summary

\begin{tabular}{|c|c|c|c|c|}
\hline Model & $\mathrm{R}$ & $\begin{array}{c}\mathrm{R} \\
\text { Square }\end{array}$ & $\begin{array}{c}\text { Adjusted } \\
\text { R Square }\end{array}$ & $\begin{array}{c}\text { Std. Error of } \\
\text { the Estimate }\end{array}$ \\
\hline 1 & $.916^{\mathrm{a}}$ & .840 & .805 & 4.039 \\
\hline
\end{tabular}

Based on the regression table above, the Adjusted R Square value is 0.805 or $80.5 \%$, meaning that the concentration diversity is influenced by $80.5 \%$ of the independent variables of duration, frequency, and intensity of gadget use.

Table 14. Coefficient of Determination $X_{1}, X_{2}, X_{3}$ to $Y_{2}$

Model Summary

\begin{tabular}{|c|c|c|c|c|}
\hline Model & $\mathrm{R}$ & $\begin{array}{c}\mathrm{R} \\
\text { Square }\end{array}$ & $\begin{array}{c}\text { Adjusted } \\
\text { R Square }\end{array}$ & $\begin{array}{c}\text { Std. Error of } \\
\text { the Estimate }\end{array}$ \\
\hline 1 & $.911^{\mathrm{a}}$ & .835 & .800 & 3.130 \\
\hline
\end{tabular}

Based on the regression table above, the Adjusted R Square value is 0.800 or $80.0 \%$, meaning that the diversity of eye fatigue complaints is influenced by $80.0 \%$ of the independent variables of duration, frequency, and intensity of gadget use.

Table 15. Coefficient of Determination $X_{1}, X_{2}, X_{3}$ to $Y_{3}$

Model Summary

\begin{tabular}{|c|c|c|c|c|}
\hline Model & $\mathrm{R}$ & $\begin{array}{c}\mathrm{R} \\
\text { Square }\end{array}$ & $\begin{array}{c}\text { Adjusted } \\
\text { R Square }\end{array}$ & $\begin{array}{c}\text { Std. Error of } \\
\text { the Estimate }\end{array}$ \\
\hline 1 & $.918^{\mathrm{a}}$ & .842 & .807 & 4.149 \\
\hline
\end{tabular}

Based on the regression table above, the Adjusted R Square value is 0.807 or $80.7 \%$, meaning that the diversity of learning motivation is influenced by $80.7 \%$ of the independent variables of duration, frequency, and intensity of gadget use. 


\section{DISCUSSION}

1. Influence Of Duration On Concentration

Based on the data above, the researcher argues that if the respondent uses most of his time to use gadgets, it can be categorized as an active user. With the most users, that is $>6$ hours, respondents may be bored with the existing lessons, or because they are looking for entertainment on the sidelines of their time. In line with research (Soemarmo, 2010) the average daily use of gadget users is \pm 4 hours 54 minutes. That's only calculated on average, and not a few if we look around that there are also those who can't resist opening their smartphone just to look at notifications for more than 30 minutes. The effect of these lifestyle changes is the increasing interest of users to exist and lead to imaging and information circulating faster, more sensitive to information and issues that are happening, causing concentration to learn to split due to focus on using gadgets.

\section{Influence Of Frequency On Concentration}

Based on the data above, the researcher argues that if the respondents use most of their time to use gadgets, the most users are $>40$ hours. According to Sarwar (2014) states that frequency is the frequency or amount of use of an element within a certain period of time. The level of frequency appears in the measure of how many times a person performs an activity. On average, every month gadget users use about 10-40 hours. The higher a person's frequency of using a gadget, the higher the negative effect. Negative effects can affect health, psychological, social, concentration, and so on.

\section{Influence Of Intensity On Concentration}

Based on the data above, the researcher argues that if the respondent uses too high a time intensity, the concentration will decrease. With the most users, namely $>120$ minutes per day or in one use, it ranges from > 75 minutes. According to Dimyati Mudjiono (2013) which states "learning concentration is the ability to focus on the lesson". In line with that, Sumartno in Rachman (2014) suggests that "learning concentration is a behavior and the focus of students' attention to be able to pay attention in every implementation of learning and be able to understand every subject matter that has been given". From the above opinion, it can be concluded that the concentration of attention is focused on the content of learning materials and the process of obtaining them. To strengthen attention to the lesson, teachers need to use a variety of teaching and learning strategies, taking into account study times and breaks.

4. Influence Of Duration, Frequency and Intensity On Concentration

The results of data analysis as described above show the effect of duration, frequency, and intensity of gadget use on the concentration of class X students at X SMKN 7 Malang. This shows that the variables of duration, frequency, and intensity of gadget use together have a significant negative effect on the variable concentration of students.

5. Influence Of Duration On Eye Fatigue

Based on the data above, the researcher argues that in this study the higher the intensity of gadget use, the more severe the complaints experienced by respondents. Due to too often staring at a computer screen or gadget with a distance that is too close. Apart from distance, too long a duration is also one of the causes of eye fatigue complaints. The right duration is about 4-8 hours a day to stare at a computer screen or gadget. The lighting factor also affects the occurrence of eye fatigue complaints. Therefore, we must wisely use gadgets and maintain eye health by adjusting the distance, duration and lighting of our computer screens or gadgets.

6. Influence Of Frequency On Eye Fatigue

Based on the data above, the researcher argues that in this study the higher the frequency of using gadgets, the higher the complaints of eye fatigue experienced by students. According to Pheasant (2010), eye fatigue is eye strain caused by impaired vision at work that requires the ability to see for long periods of time which is usually accompanied by uncomfortable viewing conditions. Meanwhile, according to Suma'mur (2008) eye fatigue arises as intensive stress on eye functions such as the accommodation muscles at work that need careful observation or on the retina as a result of contrast uncertainty.

7. Influence Of Intensity On Eye Fatigue

Based on the data above, the researcher argues that in this study the more complaints experienced by respondents, namely the respondents experienced complaints of severe eye fatigue. Complaints of eye fatigue are mainly caused by accommodation activities and excessive eye convergence when working in front of a computer or gadget. The longer a person is dealing with a gadget screen, the more radiation he receives, causing complaints that will hurt the eyes. The reason why you get eye fatigue could be due to the wrong position and the distance you use the gadget that is too close. 


\section{Influence Of Duration, Frequency And Intensity On Eye Fatigue}

The results of data analysis as described above indicate the effect of duration, frequency, and intensity of gadget use on eye fatigue complaints of class X SMKN 7 Malang. This shows that the variables of using gadgets and the learning environment together have a significant positive effect on the variable eye fatigue complaints of students.

9. Influence Of Duration On Study Learning Motivation

Based on the data above, the researcher argues that in this study, the higher the duration of using gadgets, the learning motivation will decrease. Learning motivation is one of the factors that determine effectiveness in learning. A student will learn well if there is a motivating factor, namely learning motivation (Novitasari, 2014). Students will study seriously if they have high learning motivation. The use of gadgets as a basic material for learning in children will have a positive impact such as increasing children's creativity and thinking power. This can arise if parents are good at controlling the duration of using gadgets and directing children, as well as being firm in giving time limits to children in playing gadgets (Khotimah, 2013).

10. Influence Of Frequncy On Study Learning Motivation

Based on the data above, the researcher argues that in this study the higher the frequency of using gadgets, the lower the motivation to learn. This is seen based on the aspects of the intensity of gadget use according to Ajzen (2005) namely attention, appreciation, duration, and frequency. The attention in question is that students who have gadgets will be more likely to want to use their gadgets wherever and whenever, in fact they pay more attention to their gadgets, play games rather than study, and also become lazy and forget the time. What should be studying, now spends time only on gadgets. Because attention that is in accordance with his interests will be more interesting and intensive when compared to those who have no interest in it. So that it causes students' learning motivation to decrease because part of the time is used to play gadgets.

11. Influence Of Intencity On Study Learning Motivation

Based on the data above, the researcher argues that in this study the higher the intensity of using gadgets, the lower the learning motivation. In fact, the use of smartphones does greatly affect the communication behavior of individuals. Now the smartphone has become the main communication medium. This can be proven by the reality on the ground. Everyone certainly cannot be separated from gadgets, both in communicating or simply uploading on social media. This shows that the intensity of smartphone use affects changes in individual behavior. No exception with learning motivation. Students will get motivation to learn by using gadgets with notes of intensity used in using gadgets normally and well so that they do not interfere in the learning process.

12. Influence Of Duration, Frequency, And Intencity On Study Learning Motivation

The results of data analysis as described above show the effect of duration, frequency, intensity of using gadgets on the learning motivation of class X SMKN 7 Malang students. This shows that the variables of duration, frequency, and intensity of gadget use together have a significant negative effect on the variable of student learning motivation.

\section{CONCLUSION}

There is a significant negative effect of the duration of using gadgets on the concentration of class X students at X SMKN 7 Malang. This means that if the duration of using gadgets is higher, the concentration of students' learning will decrease. There is a significant positive effect of the duration of using gadgets on eye fatigue complaints of class X students at X SMKN 7 Malang. It means, if the duration of using gadgets is higher, the students' complaints of eye fatigue will increase. There is a significant negative effect of the duration of using gadgets on the learning motivation of class $X$ students at SMKN 7 Malang. This means that the higher the duration of using the gadget, the lower the student's learning motivation. There is a significant negative effect of the frequency of using gadgets on the concentration of class X students at SMKN 7 Malang. This means that if the frequency of using gadgets is higher, the concentration of students' learning will decrease. There is a significant positive effect on the frequency of using gadgets on the eye fatigue complaints of class $\mathrm{X}$ students at $\mathrm{X}$ SMKN 7 Malang. Thus, it means that the higher the frequency of using gadgets, the more students' complaints of eye fatigue will increase. There is a significant negative effect of the frequency of using gadgets on the learning motivation of class X students at SMKN 7 Malang. This means that the higher the frequency of using gadgets, the lower the students' learning motivation. There is a significant negative effect of the intensity of using gadgets on the concentration of class X students at X SMKN 7 Malang. This means that if the intensity of using gadgets is higher, the concentration of student learning will decrease. There is a significant positive effect of the intensity of gadget use on the eye 
fatigue complaints of class $\mathrm{X}$ students at X SMKN 7 Malang. Thus, it means that the higher the intensity of using gadgets, the more students' complaints of eye fatigue will increase. There is a significant negative effect of the intensity of using gadgets on the learning motivation of class $X$ students at SMKN 7 Malang. This means that the higher the intensity of using gadgets, the lower the students' learning motivation. There is a significant negative effect of duration, frequency and intensity of using gadgets on the concentration of class X students at X SMKN 7 Malang. Thus, it means that if the duration, frequency, and intensity of using gadgets are higher, the concentration of students' learning will decrease. There is a significant positive effect of duration, frequency and intensity of gadget use on eye fatigue complaints of class X students at X SMKN 7 Malang. Thus, it means that the higher the duration, frequency, and intensity of using gadgets, the students' complaints of eye fatigue will increase. There is a significant negative effect of duration, frequency and intensity of using gadgets on the learning motivation of class X students at SMKN 7 Malang. This means that the higher the duration, frequency and intensity of using gadgets, the lower students' learning motivation.

\section{ACKNOWLEDGMENTS}

The author is thankful for respondents for their valuable information and its awareness to participate in this research.

\section{CONFLICTS OF INTEREST}

The author declares that they have no conflict of interest

Website : http://jurnal.strada.ac.id/jqph_Email : jqph@strada.ac.id

\section{REFERENCES}

A.M. Sardiman. Interaksi dan Motivasi Belajar Mengajar. (Jakarta: Rajawali Pers,2013). Hlm.75

Agusli, R. 2013. Panduan Koneksi Internet $3 G$ \& HSDPA di Handphone \& Komputer Jakarta: Mediakita.

Anwar, Abugaza. 2013. Social Media Politika. Jakarta: P.T Tali Writing \& Publishing House.

Anwar, Saiful. 2014. Metode Penelitian. Yogyakarta: Pustaka Pelajar.

Chusna Oktavia Rohmah, "Pengaruh Penggunaan Penggunaan gadget dan Lingkungan Belajar terhadap Minat Belajar Siswa kelas XI Kompetensi Keahlian Administrasi Perkantoran SMK Muhammadiyah 2 Yogyakarta", Skripsi S1 Kearsipan Fakultas Ekonomi

Crain, William. 2013. Teori Perkembangan Konsep dan Aplikasi. Yogyakarta: Pustaka Pelajar.

D.J Bearison \& B Dorvaborative. Collaborative Cognition. Sebagaimana dikutip oleh John W. Santrok, Psikologi Pendidikan. Edisi kedua terj. Tri Wibowo (Jakarta: Prenada Media Group, 2014). Hlm: 510

DEPKES RI, 2013. KEPUTUSAN MENTERI KESEHATAN NOMOR 1202/MENKES/SK/VIII/2010.www.litbang.depkes.go.id/download/is2010/ indikator.pdf. Diakses pada tanggal 22 Desember 2015.

Desi Satriani.Pratiwi,dkk. 2014. Hubungan Relatedness dengan Intensitas Penggunaan Jejaring Sosial Twitter pada Mahasiswa. Jurnal (tidak diterbitkan). Malang: Program Studi Psikologi Universitas Brawijaya.

Dimyati dan Mudjiono. "Belajar dan Pembelajaran". (Jakarta: PT Rineka Cipta, 2014). Hlm. 80

Edi S. Muliyanta. Kupas Tuntas Telepon Selular Anda. (Yogyakarta: ANDI, 2014) hlm. 1

Elida Priyitno. Motivasi dalam Belajar Mengajar. (Jakarta: P2LPTK, 2012). Hlm: 11

Evi, Nuryani. 2014. Hubungan Intensitas Mengakses Facebook Dengan Perilaku Belajar Siswa SMA NEGERI 2 Tenggarong Seberang. E-Journal Ilmu Komunikasi (tidak diterbitkan).Kalimantan Timur: Ilmu Komunikasi FISIP Universitas Mulawarman.

Fadhillah, Selisca. 2013. "Faktor-faktor yang berhubungan dengan keluhan kelelahan mata pada pengguna komputer di accounting group PT Bank X, Jakarta”. Skripsi. Fakultas Kedokteran dan Ilmu Kesehatan Universitas Islam Negeri Syarif Hidayatullah Jakarta.

Faris, muhammad kamil. "Pengaruh Penggunaan gadget Berdampak Kepada Kurangnya Komunikasi Tatap Muka Dalam Kehidupan Sehari-hari”. Skripsi S1 IAIN Raden Intan Lampung. 2016. Hlm: 40 